\title{
Variable microsatellites in the Pacific Oyster Crassostrea gigas and other cupped oyster species
}

\author{
A Huvet $^{1}$, P Boudry $^{1}$, M Ohresser $^{2}$, C Delsert $^{1}$, F Bonhomme $^{2}$ \\ ${ }^{1}$ Laboratoire Gén7eacute;tique et Pathologie, IFREMER, BP 133, 17390 La Tremblade, France \\ ${ }^{2}$ Laboratoire Génome, populations, intéractions, CNRS UPR 9060, IFREMER URM 16, Station \\ Méditerranéenne de l'Environnement Littoral, 34200 Sète, France
}

\begin{abstract}
Source/description : Genomic DNA was extracted from a whole Pacific oyster (C. gigas) after grinding in liquid nitrogen. Purified DNA was then digested by a mix of 3 restriction enzymes (Alul, Rsal, HaellI). DNA fragments ranging from 250 to 500 bp were size-selected by agarose gel electrophoresis and ligated into the dephosphorylated blunt-ended Smal-linearised pBKS2 plasmid (Stratagene Cloning System, CA). White colonies $(11,500)$ were screened by hybridisation with double-stranded DNA probes containing dinucleotide repeats. Poly(dAdC), poly(dAdG), poly(dAdT) (Pharmacia Biotech, Sweden) were mixed at equimolar ratio and radiolabelled by [ -32P] alpha dATP and dCTP using a random priming labelling kit (Life Technologies, Germany). Filter hybridisation and subsequent washing were carried out at $65^{\circ} \mathrm{C}$ in $5 \mathrm{X}$ SSC. Fifty two positive clones were identified with dinucleotide microsatellites. Plasmid DNA from minipreps performed on these positive clones were cut in the multicloning site of pBKS2 in order to determine the insert length. Plasmid DNA was prepared and sequenced using forward and reverse primers present on each side of the pBKS2 multicloning site. Only 6 positive clones contained a microsatellite motif out of the 51 sequenced. Specific primers were designed for 5 of them.

PCR reaction : Radioactive PCR amplification was carried out in a total volume of $10 \mu$ l using $2 \mu$ l of extract containing oyster genomic DNA. Reagents included dNTPs $(0.074 \mathrm{mM}), 1$ pmole of each primer, and $0.35 \mathrm{U}$ of Taq polymerase (PROMEGA, WI). Note that the $\mathrm{MgCl} 2$ concentration was optimised for each marker (Table 1). Radioactive labelling of the amplification fragment was carried out using 0.25 pmol of a primer phosphorylated with [ -33P]-ATP. After a denaturing step of 1 min at $94^{\circ} \mathrm{C}$, samples were processed through 30 cycles consisting of $1 \mathrm{~min}$ at $94^{\circ} \mathrm{C}, 1 \mathrm{~min}$ at the optimal annealing temperature (Table 1) and $1 \mathrm{~min} 15 \mathrm{sec}$ at $72^{\circ} \mathrm{C}$. The last elongation step was lengthened to 5 min.

Polymorphism : Four loci were found to be polymorphic with the primer pairs designed and exhibited a high variability (Table 1). One of the loci (L10) was scored on 324 individuals $\mathrm{C}$. gigas from different geographical origins and displayed 49 alleles. The allelic PCR products differed from each other in multiples of 2 base pairs.

Cross-species amplification : We also examined the conservation of the four polymorphic loci in 10 species of the genus Crassostrea and two of the genus Saccostrea (Table 2). PCR amplifications were performed using the same reaction conditions as above. These microsatellite loci were also amplified in closely related Asian taxa: C. angulata, C. sikamea and C. ariakensis, 3 cupped oysters of interest in aquaculture. These fragments were not sequenced but it is likely that homologous loci were amplified in these species, as they showed similar size and similar allelic variation as those obtained for $\mathrm{C}$. gigas. In addition, the primers for the L48 locus also allowed the amplification of specific products from C. gasar, C. rhizophorae, S. cucullata and S. commercialis but the yields of amplification DNA were too low to allow the identification of allelic variation.
\end{abstract}


Source/description : Genomic DNA was extracted from a whole Pacific oyster (C. gigas) after grinding in liquid nitrogen. Purified DNA was then digested by a mix of 3 restriction enzymes (AluI, RsaI, HaeIII). DNA fragments ranging from 250 to 500 bp were size-selected by agarose gel electrophoresis and ligated into the dephosphorylated blunt-ended SmaIlinearised pBKS2 plasmid (Stratagene Cloning System, CA). White colonies $(11,500)$ were screened by hybridisation with double-stranded DNA probes containing dinucleotide repeats. Poly(dAdC), poly(dAdG), poly(dAdT) (Pharmacia Biotech, Sweden) were mixed at equimolar ratio and radiolabelled by $\left[\alpha-{ }^{32} \mathrm{P}\right]$ alpha dATP and dCTP using a random priming labelling kit (Life Technologies, Germany). Filter hybridisation and subsequent washing were carried out at $65^{\circ} \mathrm{C}$ in $5 \mathrm{X}$ SSC. Fifty two positive clones were identified with dinucleotide microsatellites. Plasmid DNA from minipreps performed on these positive clones were cut in the multicloning site of pBKS2 in order to determine the insert length. Plasmid DNA was prepared and sequenced using forward and reverse primers present on each side of the pBKS2 multicloning site. Only 6 positive clones contained a microsatellite motif out of the 51 sequenced. Specific primers were designed for 5 of them.

PCR reaction : Radioactive PCR amplification was carried out in a total volume of $10 \mu \mathrm{l}$ using $2 \mu$ l of extract containing oyster genomic DNA. Reagents included dNTPs $(0.074 \mathrm{mM})$, 1 pmole of each primer, and $0.35 \mathrm{U}$ of Taq polymerase (PROMEGA, WI). Note that the $\mathrm{MgCl}_{2}$ concentration was optimised for each marker (Table 1). Radioactive labelling of the amplification fragment was carried out using $0.25 \mathrm{pmol}$ of a primer phosphorylated with $[\gamma-$ ${ }^{33} \mathrm{P}$ ]-ATP. After a denaturing step of $1 \mathrm{~min}$ at $94^{\circ} \mathrm{C}$, samples were processed through 30 cycles consisting of $1 \mathrm{~min}$ at $94^{\circ} \mathrm{C}, 1 \mathrm{~min}$ at the optimal annealing temperature (Table 1) and $1 \mathrm{~min} 15 \mathrm{sec}$ at $72^{\circ} \mathrm{C}$. The last elongation step was lengthened to $5 \mathrm{~min}$.

Polymorphism : Four loci were found to be polymorphic with the primer pairs designed and exhibited a high variability (Table 1$)$. One of the loci (L10) was scored on 324 individuals $C$. gigas from different geographical origins and displayed 49 alleles. The allelic PCR products differed from each other in multiples of 2 base pairs.

Cross-species amplification : We also examined the conservation of the four polymorphic loci in 10 species of the genus Crassostrea and two of the genus Saccostrea (Table 2). PCR amplifications were performed using the same reaction conditions as above. These microsatellite loci were also amplified in closely related Asian taxa: C. angulata, C. sikamea and C. ariakensis, 3 cupped oysters of interest in aquaculture. These fragments were not sequenced but it is likely that homologous loci were amplified in these species, as they showed similar size and similar allelic variation as those obtained for $C$. gigas. In addition, the primers for the $L 48$ locus also allowed the amplification of specific products from $C$. gasar, C. rhizophorae, S. cucullata and S. commercialis but the yields of amplification DNA were too low to allow the identification of allelic variation.

Acknowledgements : We thank André Gérard for his support during the course of this work, Sophie Launey and Anne Doye for her technical assistance and Sylvie Lapegue for comments on the manuscript. This research was supported by the European Commission (FAIR, contract PL95-421) and by an IFREMER contract URM16 to LGPI. 
Table 1. Characterisation of four polymorphic microsatellite loci in the Pacific cupped oyster C. gigas. Ta is the optimal annealing temperature, He is the expected heterozygosity and Ho the observed heterozygosity. Sample size was 17 individuals for all loci, except for the $L 10$ locus where it was 468 individuals.

\begin{tabular}{|c|c|c|c|c|c|c|c|c|c|}
\hline Locus & Repeat array & Primer sequences ( $\left.5^{\prime} \rightarrow 3^{\prime}\right)$ & $\begin{array}{c}\text { GenBank } \\
\text { accession } \\
\text { number }\end{array}$ & $\begin{array}{c}\text { Annealing } \\
\text { temperature } \\
\left({ }^{\circ} \mathrm{C}\right)\end{array}$ & $\begin{array}{c}{\left[\mathrm{MgCl}_{2}\right]} \\
(\mathrm{mM})\end{array}$ & Allele number & Ho & $\mathrm{He}$ & $\begin{array}{l}\text { Mean size range of } \\
\text { PCR product (bp) }\end{array}$ \\
\hline$L 8$ & $(\mathrm{AG})_{22}$ & $\begin{array}{l}\text { AGAGGTTCAATGACGCTGGTG } \\
\text { GATAAACAGTTTTCTGGTGTTAC }\end{array}$ & AF170849 & 57 & 1 & 14 & 0.54 & 0.85 & 181 \\
\hline$L 10$ & $(\mathrm{AG})_{26}$ & $\begin{array}{l}\text { GGTCAATTCAAAGTCAATTTCCС } \\
\text { CATGTTTTCССТTGACTGATCC }\end{array}$ & AF170850 & 55 & 1 & 49 & 0.90 & 0.96 & 136 \\
\hline$L 16$ & $(\mathrm{AG})_{24}$ & $\begin{array}{c}\text { CGGACGAATAAGATATTTGGTC } \\
\text { TGGATCTGCGCATCATCTCG }\end{array}$ & AF170851 & 57 & 1 & 15 & 0.64 & 0.83 & 164 \\
\hline$L 48$ & $(G A)_{n}>30$ & $\begin{array}{l}\text { TCAAACCATCTGCTCGTCTACG } \\
\text { TCCGAAAATCCAGGAATACCGG }\end{array}$ & AF170852 & 60 & 1.5 & 13 & 0.73 & 0.87 & 161 \\
\hline
\end{tabular}


Table 2. Cross-species amplification for 4 microsatellite loci

\begin{tabular}{|c|c|c|c|c|c|}
\hline \multirow[b]{2}{*}{ Species } & \multirow[b]{2}{*}{$\mathrm{N}$} & \multicolumn{4}{|c|}{ Locus } \\
\hline & & $\begin{array}{l}\text { L8 } \\
\end{array}$ & L10 & L16 & L48 \\
\hline Crassostrea angulata & 10 & + & + & + & + \\
\hline Crassostrea ariakensis & 5 & - & $1+$ of 5 tested & + & + \\
\hline Crassostrea sikamea & 5 & - & + & + & + \\
\hline Crassostrea virginica & 5 & - & - & $1+$ of 5 tested & + \\
\hline Crassostrea iredalei & 1 & - & - & - & - \\
\hline Crassostrea belcheria & 1 & - & - & - & - \\
\hline Crassostrea margaritacea & 3 & - & - & - & - \\
\hline Crassostrea echinata & 5 & - & - & - & - \\
\hline Crassostrea gasar & 5 & - & - & - & $?$ \\
\hline Crassostrea rhizophorae & 4 & - & - & - & $?$ \\
\hline Sassostrea cucullata & 5 & - & - & - & $?$ \\
\hline Sassostrea commercialis & 4 & - & - & - & ? \\
\hline
\end{tabular}

+ amplification, - no amplification, ? slight amplification without reading the genotypes 